\title{
STATE-BUSINESS RELATIONS FROM THE PERSPECTIVE OF THE COMPANIES' PREPAREDNESS FOR THE CHANGES RELATED TO INDUSTRY 4.0: A CASE OF THE CZECH REPUBLIC
}

\author{
Olšanová, K., Křenková, E., Hnát, P., Vilikus, $\mathrm{O}$.
}

Květa Olšanová / Prague University of Economics and Business, Faculty of International Relations, Department of International Business, W. Churchill Square 4, 13067 Prague 3, Czech Republic. Email: kveta.olsanova@vse.cz

Eva Křenková / Prague University of Economics and Business, Faculty of International Relations, Department of International Business, W. Churchill Square 4, 13067 Prague 3, Czech Republic. Email: eva.krenkova@vse.cz

Pavel Hnát / Prague University of Economics and Business, Faculty of International Relations, Department of International Economic Relations, W. Churchill Square 4, 13067 Prague 3, Czech Republic.Email: pavel.hnat@vse.cz

Ondrej Vilikus / Prague University of Economics and Business, Faculty of Informatics and Statistics, Department of Statistics and Probability, W. Churchill Square 4, 13067 Prague 3, Czech Republic. Email: ondrej.vilikus@vse.cz

\section{Abstract}

The purpose of this study is to investigate the expectations of the management of different industries in the Czech Republic related to governmental support for their implementation of Industry 4.0 and their preparedness for the challenges associated with these technological changes. Mixed research, specifically exploratory sequential design, was used. The findings of qualitative data analyses from in-depth semi-structured interviews $(n=41)$ with representatives of different industry sectors formed subsequent quantitative data collection ( $\mathrm{N}=146$, the board of management members representing various industries) through survey items corresponding with formalized research questions. The findings revealed a strong group of companies already implementing Industry 4.0 elements (85\% of respondents) driven by companies with $250+$ employees. As perceived by the management, the critical threat related to the workforce is a lack of skilled labour. Managers tend to prefer a transparent business environment without state interventions or interventions targeted to strategic state industries, preferably to the spheres of education, research \& development, energy sector, sustainable agriculture, and healthcare. The results indicate that the easier administration and education reform are among the companies' boldest expectations from the government, among general conditions for current business.

Implications for the Central European audience: Central European companies face challenges related to implementing the Industry 4.0 elements. Therefore, the findings that aim to contribute to the debate addressing administration simplification, business environment transparency, and reform of the education system are considered relevant for the CE audience. 
Keywords: state-business relations; Industry 4.0; Government support; subsidies

JEL Classification: H25, H52, L25, M10, O33

\section{Introduction}

The term "Fourth Industrial Revolution" (4IR) has been used since January 2016, when the World Economic Forum Founder and Executive Chairman, Klaus Schwab, published an eponymous book. The term is being used to frame and analyze the impact of emerging technologies on society in the 21 st century, including evolving social norms and national political attitudes on economic development and international relations. From the transformation point of view, the term highlights the idea that at certain stages in history, including the current one, "sets of technologies emerge and combine in ways that have an impact far beyond incremental increases in efficiency." Industry 4.0 relates to the application of digital technologies to manufacturing and comes from Germany, evolving between 201115. Therefore $4 \mathrm{IR}$ should be read as a broader term with Industry 4.0 as its essential component focusing on the "relationship between digitization, organizational transformation, and productivity enhancement in manufacturing and production systems" (Philbeck \& Davis, 2019, p. 17).

Critical components of Industry 4.0 include autonomous and collaborative robots, the internet of things, additive manufacturing, cloud computing, augmented reality, big data, cyberphysical systems (CPS), and smart factories (Ayşe Göksu et al., 2018; Hermann et al., 2016). One recent literature review related to the adoption of Industry 4.0 highlights the role of government in supporting the industry by developing national or regional policies based on four pillars: "(i) Education plans that pay much more attention to manufacturing topics and put more stress on foreign languages; (ii) Investment plans that also encourage middle-sized companies to adopt Industry 4.0; (iii) Plans for education focused on computer science and continuous education for the aforementioned intelligent factory operators; (iv) Policies to deal with the social structure problem due to low birthrate, income instability, work-family imbalance, etc." (Marešová et al., 2018, p. 10; Sung, 2018).

This research paper aims to explore the companies' preparedness in the Czech Republic for the changes related to the implementation of the components of Industry 4.0 and their expectations from the government to help them remain competitive. Within this paper, we do not aim to investigate the efficiency of different forms of public support but instead explore what the industry representatives consider a threat to their Industry 4.0 journey and how important the role of governmental aid is to them.

The paper is structured as follows. Firstly relevant sources related to the industry preparedness for the changes associated with Industry 4.0 and different state aid approaches in the innovation processes are reviewed. In the next part, the research methods are introduced, data obtained from the qualitative ( $\mathrm{n}=41$ companies) and quantitative $(\mathrm{N}=146$ companies) phases are interpreted and analyzed by answering a set of research questions. The mixed research results are illustrated by the joint display. Finally, the results are discussed, and the implications for the relevant stakeholders are suggested. 


\section{Industry preparedness for the changes related to Industry 4.0}

According to Deloitte's survey amongst 1,603 global executives conducted in 2017, only $14 \%$ of executives are highly confident that their organizations are ready to harness the changes associated with Industry 4.0 entirely. Moreover, they lack confidence that they have the right talents in place to be successful. Concerning the investment behind technologies, they understand the need for it but confirm limitations due to internal strategic alignment and their planning's short-term focus (Deloitte, 2018).

Considering the 4IR as an evolution rather than a revolution, research findings show that the companies that are either adopting or implementing digital technologies these days are more likely to implement advanced digital technologies in the days to come. The digital base creates conditions for implementing new solutions, and through newly installed processes, interconnection and experience boost the environment enabling business innovations (Anaya et al., 2015). It means that digital preparedness is critical for future competitiveness. The survey conducted by the Confederation of Industry of the Czech Republic (2019) reveals that $32 \%$ of investigated companies reported that they have no digital strategy yet, another $30 \%$ were developing one, and $36 \%$ were already implementing it. The main drivers to adopt new technologies related to Industry 4.0 were raising productivity, cost-cutting, optimizing resources, lack of personnel, introducing new services, flexibility in production, and acceleration of $R \& D$.

The Czech companies' innovation activities were explored to frame and quantify the investments behind new technologies. According to the Czech Statistical Office (2020), the companies have spent about EUR 6 Billion on innovations of products and processes in 2018 (i.e., $2.1 \%$ of their total revenues). Out of it, $52 \%$ on machines and other devices, software, and real estate; $25 \%$ on internal R\&D and $17 \%$ on outsourced R\&D and purchase of external knowledge such as patents or licenses, $6 \%$ of expenses remain unspecified. The large proportion of the innovations spends behind products and processes (52\%) are interpreted as "adaptable nature of innovations, when companies in the Czech Republic tend to adopt advanced technologies and production processes and implement them in their productions" (Czech Statistical Office, 2020, p. 26). From the industry sizing perspective, only $41 \%$ of small enterprises (less than 50 employees, SMEs) have implemented any product or process innovation between 2016 and 2018 (Czech Statistical Office, 2020). The difference between small and large companies is also suggested by Basl and Kopp (2017), who evaluated the Czech industry's preparedness for the changes related to Industry 4.0. They argued that more than $77 \%$ of the companies had not implemented any changes yet. Their sample consisted of random employees of Czech joint-stock companies. The authors concluded that the readiness level grows with the company's size, while the small companies mostly did not consider implementing any changes. The authors explained this by being poorly informed about the potential benefits and impacts of Industry 4.0 implementation. Vrchota et al. (2020) found a positive relationship between the implementation of Industry 4.0, the sizes of the companies, and selected industries (mainly commercial activities, agricultural, and construction).

The constraints to adopting new technological solutions specifically in SMEs are personal and management capacities, the lack of capital, limited access to loans, and limitations of 
receiving public financial support (Busom et al., 2014). This is where state support can play its central role, as noted by Aiello et al. (2019), who also point out the warning signs related to potential dependency on public funds, e.g., on a state or the EU budget. The Czech Republic's case might prove evidence since venture capital expenditures have significantly decreased in 2019 compared to 2012. Simultaneously, the R\&D expenditures in the public sector have moderately increased (European Commission, 2020a). In the Czech Republic, the situation is emphasized by mostly foreign-owned banks, which can make the loans more difficult to attain for SMEs.

Compared to other countries, Czech companies' innovation activity scores below the EU's average and is mainly driven by large companies (European Commission, 2020b). The direct and indirect public support in R\&D in 2018 reached EUR 304 Mio and was allocated in the form of national subsidies (46\%), tax incentives (34\%), and subsidies from European Structural and Investment funds (20\%). The R\&D budget's central part was dedicated to personal and other operational costs, while just about $10 \%$ are capital assets (Czech Statistical Office, 2019). The forms and roles of government support are investigated further in detail.

\section{Government support}

Previous studies related to the topic suggest that the role of subsidies and other governmental support is not adequately evaluated. Buigues and Sekkat (2011) compare the design and outcome of public contributions to business across many industrialized countries. They conclude that the impact of public support policies remains remarkably "under-researched although most programs affect domestic resource allocation, competitiveness, and income distribution" (Buigues \& Sekkat, 2011, p. 23). The key reason for no empirical investigation of public subsidies' effectiveness is, according to them, the lack of a single definition and indicators. Most data related to subsidies were compiled for different reasons (OECD, WTO, EU). It limits mapping the subsidy data into one set of information.

In the EU, the European Commission has made a vast effort to define a standard course that should keep European firms competitive on global markets and ensure sustainable economic growth (European Commission, 2020a). This strategy is communicated and implemented on the national and local levels using instruments, mainly subsidies, support of education, and $\mathrm{R} \& \mathrm{D}$ institutions. EU defines state aid as "an advantage in any form whatsoever conferred on a selective basis to undertakings by national public authorities." There are some listed features of the state aid: (i) intervention by the state or through state resources which can take a variety of forms (e.g., grants, interest and tax reliefs, guarantees, government holdings of all or part of a company, or providing goods and services on preferential terms); (ii) the intervention gives the recipient an advantage on a selective basis (e.g., to specific companies or industry sectors, or companies located in particular regions); (iii) competition has been or may be distorted; and (iv) the intervention is likely to affect trade between the Member States (European Commission, 2019)

Referring to (i) above, states support businesses most commonly directly in subsidies and indirectly through tax incentives. Tax incentives are considered more neutral than subsidies as they are granted automatically without a competitive procedure related to subsidies (Aiello et al., 2019). Tax incentives are non-discriminatory in terms of technology or industry sector selection, and compared to subsidies. They are associated with less administration for both 
the applicant and the state. Moreover, Maroušek et al. (2015) argue that the allocation of subsidies is inefficient and promotes a policy of burdening market inefficiencies with taxations instead of supporting innovations with subsidies. Referring to (ii) above, the direct support can be targeted at the best projects and narrowly focus on meeting the policy targets (Carvalho, 2011). There is a noticeable difference in the structure of state support between the individual EU member states. In the Czech Republic, Slovakia, Slovenia, and Austria, there is prevailing direct state support. On the contrary, in the Netherlands, Ireland, and France, the indirect governmental support through tax incentives preponderated (European Commission, 2017).

The number of research efforts is dedicated to government financial support to businessperformed $R \& D$ in subsidies. It is believed that it can incentivize innovations and stimulate productivity growth in terms of innovations in production, acquisition of new production equipment, or increased technological transfer (Minford \& Meenagh, 2019).

The critical issue that the researchers face seems to be the availability of data both from companies who have received subsidies and from those who didn't benefit from any subsidies in the given time frame (Aiello et al., 2019). Another important question relates to the methodology of research studies: such as in what time frame should the potential changes be observed and whether there will be available company data for an extended time frame (long-tern observations) (Czarnitzki \& Delanote, 2015; Čadil et al., 2016; Kang \& Park, 2011).

R\&D expenditures, the number of patents (Minford \& Meenagh, 2019), and R\&D employment intensity (Czarnitzki \& Delanote, 2015) most commonly measure innovation performance. Ravšelj and Aristovnik (2018) proved a positive link between tax incentives, R\&D expenditures, and corporate growth. They divided companies into subgroups based on R\&D intensity and indicated the positive effect of tax incentives in high-tech and low-tech industries. Kang and Park (2011) confirmed a positive impact of government support on innovation performance measured by patenting outcomes in biotechnology, i.e., a scienceintensive sector. Czarnitzki and Delanote (2015) see a high positive effect of subsidies for young, small, and independent high-tech firms. The impact of investments in innovation and modernization in the European region was evaluated by another research team who narrow their focus on SMEs (95.7\% of the sample) in the food processing business industry. Dvouletý and Blažková (2019) suggested a positive effect on labour productivity but a negative impact on total factor productivity. A possible explanation of the negative relationship is that the investments were used to increase production rather than into technological development. Such investments don't have the anticipated positive effect on economic growth. Increased competitiveness and innovation performance targeted by this investment subsidy have not been achieved within the period under observation.

On the contrary, Tunali and Fidrmuc (2015) investigated the effect of state aid policy on economic growth and investment, using a panel data set covering 27 European Union countries over 1992-2011. They examined the EU state support divided into total state aid, state aid to industry and services, horizontal and sectoral state aid. Horizontal aid in regional development, environment (including energy-saving), research development and innovation, SME's (including risk capital), while sectoral included assistance in rescue and restructuring, transport, agriculture, fisheries and aquaculture, coal, steel, and shipbuilding. The authors suggested that state aid policy is not a useful tool to achieve higher economic growth and 
investment rates. Importantly, their result confirmed that both economic freedom and political stability have a positive and statistically significant effect on investment.

Aiello et al. (2019) did not find any significant influence of the public support on the number of patents registered in the post-policy period. Even though the number of innovative inputs (and the amount spent on R\&D) had increased in the police period: "The evidence indicates that the return of the innovative efforts made in generating patents is lower for publicly funded expenditure" (Aiello et al., 2019, p. 1068).

The influence of existing state incentive opportunities might be lower in R\&D intensive firms than less $R \& D$ intensive because research-driven companies are less likely to change their behaviour because of an existing subsidy option (Karhunen \& Huovari, 2015). Čadil et al. (2016) deal with direct R\&D public support in the form of subsidies to the private sector from the point of view of its initial application phase. They compared the successful applicants' and rejected applicants' financial indicators such as profit, assets, sales, gross value added, and personnel expenses. They found no statistically significant difference between the supported and not supported (rejected) firms and concluded that the state R\&D subsidies to private firms might have a limited effect in the short run.

There is no clear preference for any of the instruments amongst different company sizes. SME's might be facing more constraints receiving loans, and therefore the direct state support in the form of subsidies might seem more relevant to them. However, these companies might be motivated to learn more about the state aid programs since, with the increase of financial constraints, the chance to receive a subsidy decreases (Barbosa \& Silva, 2018). SME's are more sensitive to financial constraints and demand uncertainty, which are clear barriers to innovation. Other obstacles to innovation are the presence of a dominant firm, lack of information, and, notably, the lack of personnel. Romijn and Albaladejo (2002) expressed a concern of small companies that a successful grant application requires an applicant's skills in drafting a project which is a limiting factor to companies with no previous experience or lack of specialists. Busom et al. (2014) suggest that prior experience with R\&D increases the likelihood of using any form of state aid to support their innovation activity.

Also, indirect state aid tools can increase the rate of technological changes in the economy and foster the readiness for technological changes in general. Public subsidies aiming to facilitate cooperation with external organizations can enhance innovation performance (Greco et al., 2017; Mewes \& Broekel, 2020). Collaboration enables knowledge and capabilities transfer among businesses. Cooperating firms are benefiting from sharing resources and knowledge to access complementary capabilities and expertise. Outsourcing can also play this role. These linkages can be especially contributive in value chains, encouraging cooperation among producers and suppliers. To gain a premium result from building an influential network that will positively stimulate a firm's innovation capabilities can be most stirred when the linkages are created on international and domestic levels (Srholec, 2014).

While observing companies' preparedness to implement new technologies in working processes, employees' roles should be considered (Santos \& Martinho, 2019). The state's part is in the education system encompassing schools and universities and training either organized directly by the state institutions or financially supported by subsidies. The wide use of Industry 4.0 technologies creates new challenges for management and employees. First, 
there is the problem of lack of experts (Czech Statistical Office, 2018), second, changed working conditions create the need for new workforce capabilities (Veile et al., 2019).

\section{Research Methodology}

In the present study, the qualitative data analyses and results were used to build the quantitative measures. Findings are interpreted through joint display as used in exploratory sequential designs, where the qualitative data are firstly collected, analyzed and these findings form following quantitative data collection (Onwuegbuzie et al., 2010), (Fetters et al., 2013); i.e., qualitative methods are used to help develop quantitative measures and instruments (Creswell et al., 2003). The integration of qualitative and quantitative research at the methods level is in the present study done through a building, i.e., items for inclusion in a quantitative survey are built upon previously collected qualitative data that identify constructs or language used by respondents as corresponding quantitative survey items. Integration at the interpretation level is elaborated through the joint display (Fetters et al., 2013). Through the initial qualitative research, the focus is on meanings and gaining a deeper understanding of the relevant issues rather than on quantifiable phenomena; depth, details, and sensitivity to context are emphasized rather than seeking universal generalization (Schutt, 2015). The qualitative part serves as instrument development, employed to develop research questions, corresponding survey items for the upcoming quantitative phase (Bryman, 2006; Fetters et al., 2013; Sreejesh \& Mohapatra, 2014). Consequently, the quantitative stage's descriptive statistics, including one-way ANOVA with Tukey post hoc test, are used to understand the subgroups' differences as ground explaining stated research questions.

\subsection{Methodology of the in-depth interviews}

In-depth interviews with selected representatives of the company's top management took place at its headquarters based on a semi-structured questionnaire divided into five main sections (perception of Industry 4.0, R\&D, employee skills/knowledge, education, and forms of investment support). The length of the interviews ranged from 60 to 130 minutes; the average interview lasted 70 minutes. Data collection took place from December 2019 to February 2020 through 11 interviewers from the Department of World Economics and the Department of International Trade of the Faculty of International Relations of the Prague University of Economics and Business. Representatives of the Czechlnvest (a state contributory organization subordinated to the Ministry of Industry and Trade of the Czech Republic (CzechInvest, 2020) attended some interviews. The respondents' pre-selection was based on the Czechlnvest database to cover all Czech Republic regions and different industry sectors and company sizing. The final list with a detailed description is included in Appendix 1.

The sample included 41 companies from all 14 regions of the Czech Republic, whose relative amount of R\&D expenditure was up to $10 \%$ of the revenue. $93 \%$ of the addressed companies also operate in foreign markets. A quarter of companies had Czech origin in terms of ownership, followed by German, British, American, Dutch, Swiss, French, and other companies (i.e., UK, KR, AT, BE). Companies from various industry sectors were addressed (information technology, electrical and pharmaceutical industry, research and development, production of other means of transport, aerospace, electronics, engineering and chemical industry, rubber and plastics, metalworking, engineering, furniture production, construction, and other manufacturing). 
The interviews were transcribed in MS Excel and uploaded to NVivo. The data coding was conducted by three independent researchers with two consecutive sets of corrections after coding comparison queries.

The thematic codes (nodes) were set up as analytical ones, aiming to understand the meaning in context. The set of codes (nodes) was constructed based on supportive theoretical themes from the literature and initial observation of all the cases (Sekaran \& Bougie, 2009) as follows: (i) formal education, (ii) skills and competencies, (iii) investment and financing (i-iii Marešová et al., 2018); (iv) critical threats, (v) main drivers to adopt new technologies, (vi) Industry 4.0 elements adopted or planned (iv-vi Confederation of Industry of the Czech Republic, 2019); (vii) public financial support and (viii) issues with public financial support (Aiello et al., 2019; Busom et al., 2014). The interpretation was made through coding and thematic analysis of qualitative data (Creswell et al., 2003) using the word frequencies and relevant text search queries to understand the context. A set of themes that emerged from the interpretation was employed to form the research questions for the quantitative phase.

\subsection{Methodology of the quantitative survey}

The questionnaire survey took place in the first quarter of 2020 by interviewers from Kantar CZ. Data collection was completed before the government declared a state of emergency caused by COVID-19 on the $12^{\text {th }}$ of March 2020 . The recruitment screening was based on the database Albertina ${ }^{1}$ using CATI (Computer Assisted Telephone Interviewing) targeting the sectors pre-defined due to higher affinity towards Industry 4.0 in three different company sizing with an expected reach 1:150. The survey itself was conducted in CAWI (Computer Assisting Web Interviewing), the final sample ( $\mathrm{N}=146)$ consisted of a board of management representatives of small companies (up to 49 employees, $36 \%$ of the full sample), $40 \%$ of mid-sized companies (50 - 249 employees), and $24 \%$ of large ( $250+$ employees) who were screened in for agreement with the statement that the current technological challenges (explained) have an impact on their company.

The questionnaire structure was based on the interpretation of the previous qualitative study. The recruitment filters were set to get a sample from the board of management level and ensure different company sizes, industries, and geography. The analytics part uses descriptive statistics of the results with multiple comparisons of the means where necessary (Tukey HSD). Detailed sample description by company sizes, industry type, and experiences with subsidies is summarized in Table 1 (resp. Table 1a).

${ }^{1}$ https://www.bisnode.cz/produkty/albertina/ 
Table 1 | Sample description (structure by company sizes)

\begin{tabular}{|c|c|c|c|c|c|c|c|c|}
\hline & \multicolumn{2}{|c|}{ All } & \multicolumn{2}{|c|}{$\begin{array}{c}\text { Up to } 49 \\
\text { employees }\end{array}$} & \multicolumn{2}{|c|}{$\begin{array}{c}50-249 \\
\text { employees }\end{array}$} & \multicolumn{2}{|c|}{$\begin{array}{c}250+ \\
\text { employees }\end{array}$} \\
\hline & $\mathbf{N}$ & $\%$ & $\mathbf{N}$ & $\%$ & $\mathbf{N}$ & $\%$ & $\mathbf{N}$ & $\%$ \\
\hline All & 146 & 100 & 53 & 36 & 58 & 40 & 35 & 24 \\
\hline Experience with gov. local subsidies & 34 & 23 & 11 & 21 & 12 & 21 & 11 & 31 \\
\hline Experience with European subsidies & 82 & 56 & 13 & 25 & 42 & 72 & 27 & 77 \\
\hline No experience with subsidies & 54 & 37 & 35 & 66 & 12 & 21 & 7 & 20 \\
\hline Base & 146 & 100 & 53 & 100 & 58 & 100 & 45 & 100 \\
\hline
\end{tabular}

Source: own processing

Table 1a | Sample description (structure by sectors)

\begin{tabular}{lcc}
\hline & N & $\%$ \\
\hline Number of respondents & 146 & 100 \\
Automotive (NACE 29) + aerospace (NACE 30.3) & 22 & 15 \\
Electrotechnical industry (NACE 27) & 24 & 16 \\
Advanced manufacturing (NACE 26, NACE 28, NACE 32.2, NACE 32.5) & 34 & 23 \\
IT (NACE 62, NACE 63) & 27 & 18 \\
Life sciences (NACE 86 (healthcare), NACE 21 (pharmaceutical)) & 28 & 19 \\
Nanotechnologies (NACE 72.1 (R\&D in science), NACE 28.99 & & \\
(manufacture of other particular purpose machinery)) & 11 & 8 \\
\hline
\end{tabular}

Source: own processing

\section{Interpretation of the in-depth interviews}

Company managers perceive Industry 4.0 as an opportunity to increase efficiency. At the same time, the leaders tend to express concerns about the possible impact on their competitiveness due to the high investment intensity of the components related to Industry 4.0. Digitization, automation, and robotics are the most frequently mentioned elements in which companies invest or plan to invest in connection with Industry 4.0. The threats perceived in association with Industry 4.0 relate primarily to employees' preparedness and competition concerns. Competition is also one of the forces pressuring companies to implement the changes. On occasions, an increase in production efficiency prevails. Newly planned investments are even more technologically and financially demanding than the ones introduced so far. In addition to the mentioned automation and robotization, they also include data management and the use of 3D printing. Supportive quotes and word clouds based on word frequencies are summarized in Figure 1. 


\begin{tabular}{|c|c|}
\hline \multicolumn{2}{|c|}{ Node: Industry 4.0 elements adopted or planned } \\
\hline \multirow[b]{2}{*}{ 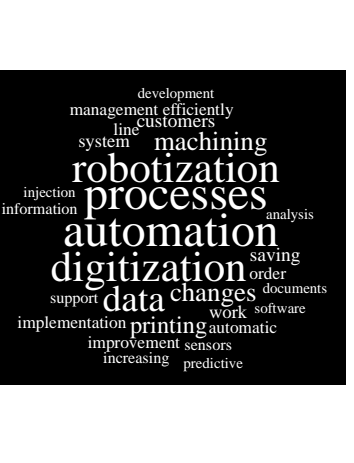 } & $\begin{array}{l}\text { "We are introducing automation to production. Looking forward: IoT, big } \\
\text { data, 3D printing for prototyping, predictive maintenance". }\end{array}$ \\
\hline & $\begin{array}{l}\text { "We have realized robotization in the injection plant saving } 18 \\
\text { employees, automatic production line saving } 20 \text { employees, robotization } \\
\text { in administration saving three employees in business data management. } \\
\text { The most significant savings we realized in production by investment in } \\
\text { injection molding room with return on investment } 12 \text { months." } \\
\text { "3D printing, automation/robotization, process digitization, data analysis, } \\
\text { sensors, IT-supported process changes, digital library (link to research } \\
\text { and development), production, warehouse, and back, etc. Now we have } \\
\text { world-class equipment, but the implementation was not easy. We have } \\
\text { been working on it for two years, and if we didn't know the whole thing } \\
\text { properly, it probably wouldn't have worked." }\end{array}$ \\
\hline \multicolumn{2}{|c|}{ Node: Main drivers to adopt new technologies } \\
\hline \multirow{3}{*}{ 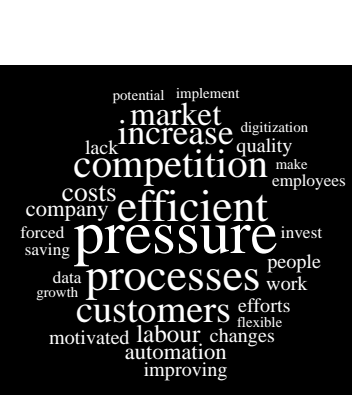 } & $\begin{array}{l}\text { "Above all, the pressure of competition, which is reflected in the pressure } \\
\text { to reduce costs. We are forced to save } 6-8 \% \text { annually on the } \\
\text { development of new products. Furthermore, labor shortages and efforts } \\
\text { to make up for the lack of labor in the future." }\end{array}$ \\
\hline & \\
\hline & $\begin{array}{l}\text { "We are facing the possibility of greater productivity and efficiency of } \\
\text { work. That is what leads us into the investments behind the elements of } \\
\text { Industry 4.0." }\end{array}$ \\
\hline \\
\hline \multicolumn{2}{|r|}{ Node: Key threats } \\
\hline \multirow{4}{*}{ 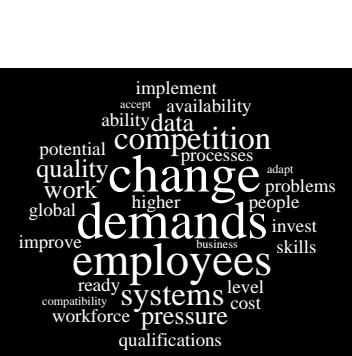 } & $\begin{array}{l}\text { "We feel pressure to reduce costs further, and also we are concerned of } \\
\text { growing competition, from Turkish producers as an example. }\end{array}$ \\
\hline & $\begin{array}{l}\text { Additionally, we strongly perceive potential problems with the availability } \\
\text { of labor force." }\end{array}$ \\
\hline & $\begin{array}{l}\text { "We can expect faster development of competition thanks to new } \\
\text { technologies that they might implement with relation to the Industry } 4.0 \\
\text { elements." }\end{array}$ \\
\hline & $\begin{array}{l}\text { "We face unavailability of suitable qualified workforce and ability or } \\
\text { willingness to change positions, change the working habits and ability to } \\
\text { learn." }\end{array}$ \\
\hline & $\begin{array}{l}\text { "The main threat we see is the workforce and its adaptability, ability to } \\
\text { accept changes and to adapt to new environments and demands." }\end{array}$ \\
\hline
\end{tabular}

Source: NVivo 12.0 (QSR International)

Figure 2 streamlines the findings leading to the formation of the first research question to better understand and quantify the scale of implementation of various Industry 4.0 elements by a more representative sample of the Czech companies of different sizing and industries. 
Figure 2 | Formation of RQ1: Are there any differences in companies' level of implementation of the elements of Industry 4.0 by industry sectors and by company sizes?

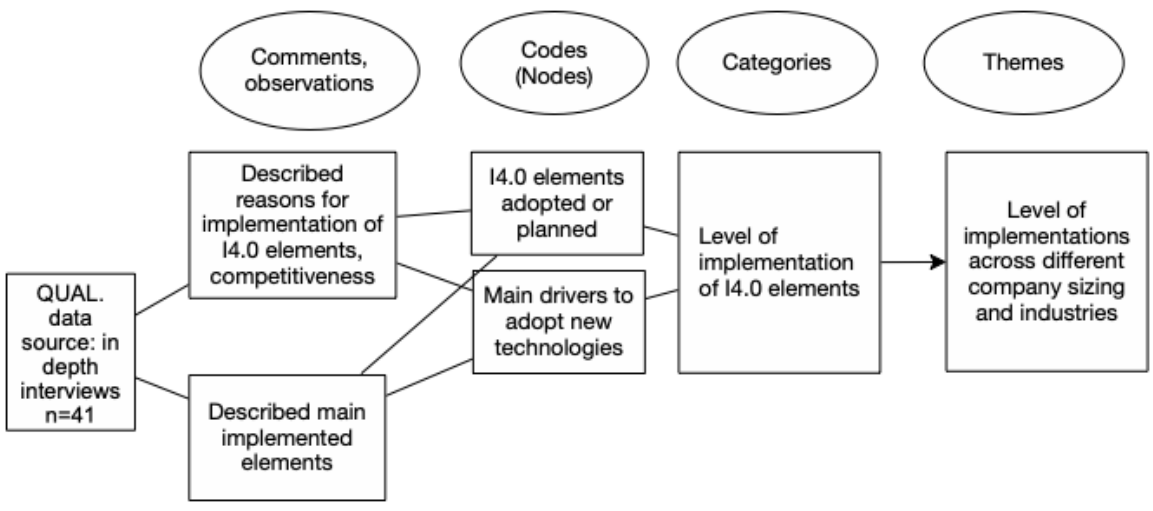

Source: own processing

Regarding the employee's skills and competencies, managers tend to emphasize critical thinking, independence, creativity, and loyalty, i.e., skills often lacking or not meeting companies' expectations (Figure 3). 'Graduates' language skills are usually well perceived.

Figure 3 | World frequencies for selected codes and illustrative quotes

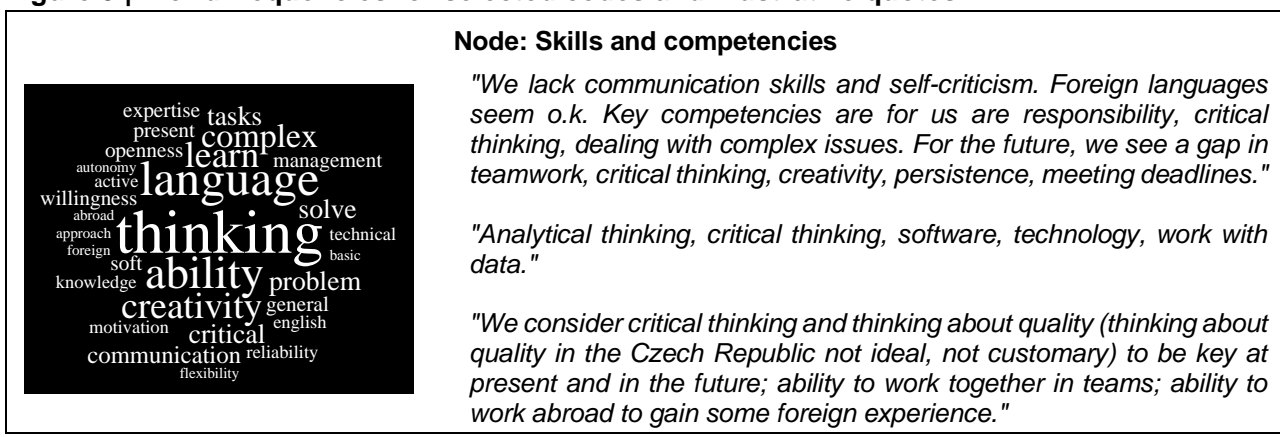

Source: NVivo 12.0 (QSR International)

During the discussion related to the formal education outcomes, the managers expressed a relatively positive evaluation of graduates' language skills except for technical graduates. Educational shortcomings were experienced in STEM knowledge (math predominantly), technical education, and technical expertise. Professional skills, craftmanship, or manual skills from higher vocational education were perceived as rather insufficient. Some respondents mentioned the education system structure as not responding to the needs of the business in the Czech Republic traditionally based on mechanical engineering. Discussion about the formal education system leads some respondents to conclude the need to reform the current education system (Figure 4). 


\begin{tabular}{|c|c|}
\hline & Node: Formal education \\
\hline & $\begin{array}{l}\text { "Improving the education system and changing the thinking of children } \\
\text { and parents about where to go." }\end{array}$ \\
\hline & $\begin{array}{l}\text { "Mathematics and technical thinking are missing. There is a lack of } \\
\text { people in higher vocational education to choose from." }\end{array}$ \\
\hline $\begin{array}{l}\text { thinking } \\
\text { improving cooperate } \\
\text { confidence vocational } \\
\text { techati dual } \\
\text { quality } \\
\text { general SVStem data }\end{array}$ & $\begin{array}{l}\text { "The formal education is quite satisfactory except for the secondary } \\
\text { vocational education is really bad. They used to teach the craft, today } \\
\text { graduates cannot do the craft and calmly even think about university." }\end{array}$ \\
\hline $\begin{array}{l}\text { progans } \\
\text { subjects } \\
\text { leann } \\
\text { learn } \\
\text { Knowled stem } \\
\text { chigher practice secondary } \\
\text { management level problem }\end{array}$ & $\begin{array}{l}\text { "Overall, we feel that the education system does not reflect the needs of } \\
\text { businesses. More vocational education and less higher education is } \\
\text { needed. On the other hand, graduates are more self-confident, better at } \\
\text { computer skills, languages but have not enough professional skills. }\end{array}$ \\
\hline & $\begin{array}{l}\text { "We lack graduates with engineering education who are interested in } \\
\text { technologies. The English language is also a weakness amongst } \\
\text { technical graduates." }\end{array}$ \\
\hline & $\begin{array}{l}\text { "We positively evaluate dual education in Germany since there is more } \\
\text { interaction with firm even before taking up employment." }\end{array}$ \\
\hline
\end{tabular}

Source: NVivo 12.0 (QSR International)

Since the workforce preparedness for the changes related to the adoption of Industry 4.0 elements was perceived as one of the critical threats and issues related to the level of skills and competencies were discussed with the respondents, the theme related to key threats perceived by the managers related to the workforce will be explored as the second research question in quantitative phase (Figure 5).

Figure 5 | Formation of RQ2: How is the Industry 4.0 preparedness of the labour force evaluated by the managers, and to what extent is it perceived as a threat? How does it differ by company sizes?
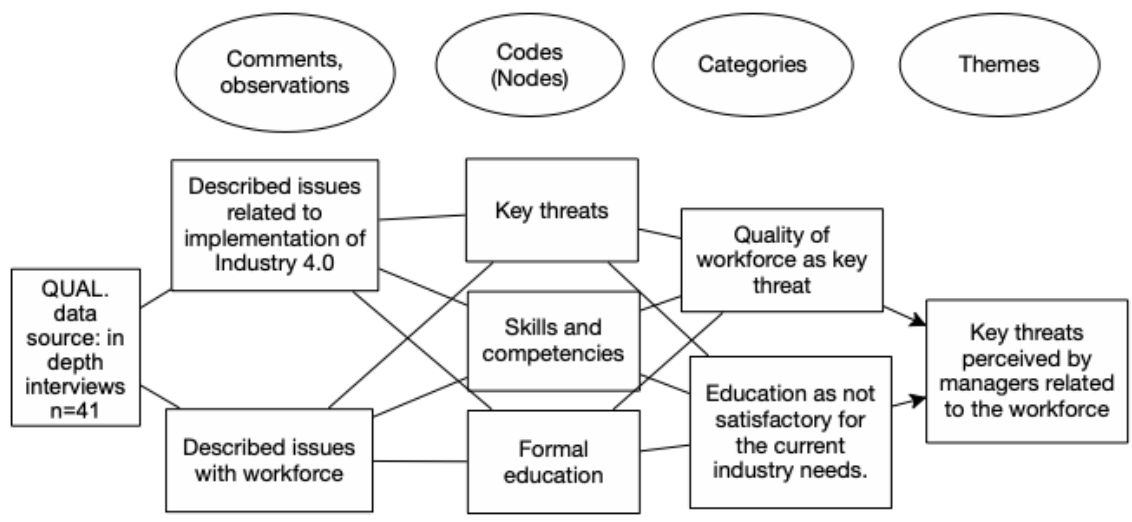

Source: own processing

Own resources and subsidies (where applicable due to the company's size or region) tend to be the primary forms of financing changes related to Industry 4.0 (Figure 6). The use of subsidies was often mentioned in companies' samples (namely MPO, TAČR, Czechlnvest, OPPIK, Trio, ESF, Horizon). It was identified that the managers do not distinguish between European and national subsidies. Companies' positive attitude to use national or European 
subsidies to increase their investment expenditures or expenditures on employee training seemed to be limited by complex administration, which was the primary factor discouraging companies from drawing more subsidies more actively unless they have an experienced external specialist as employee or external agency.

Figure 6 | World frequencies for selected codes and illustrative quotes

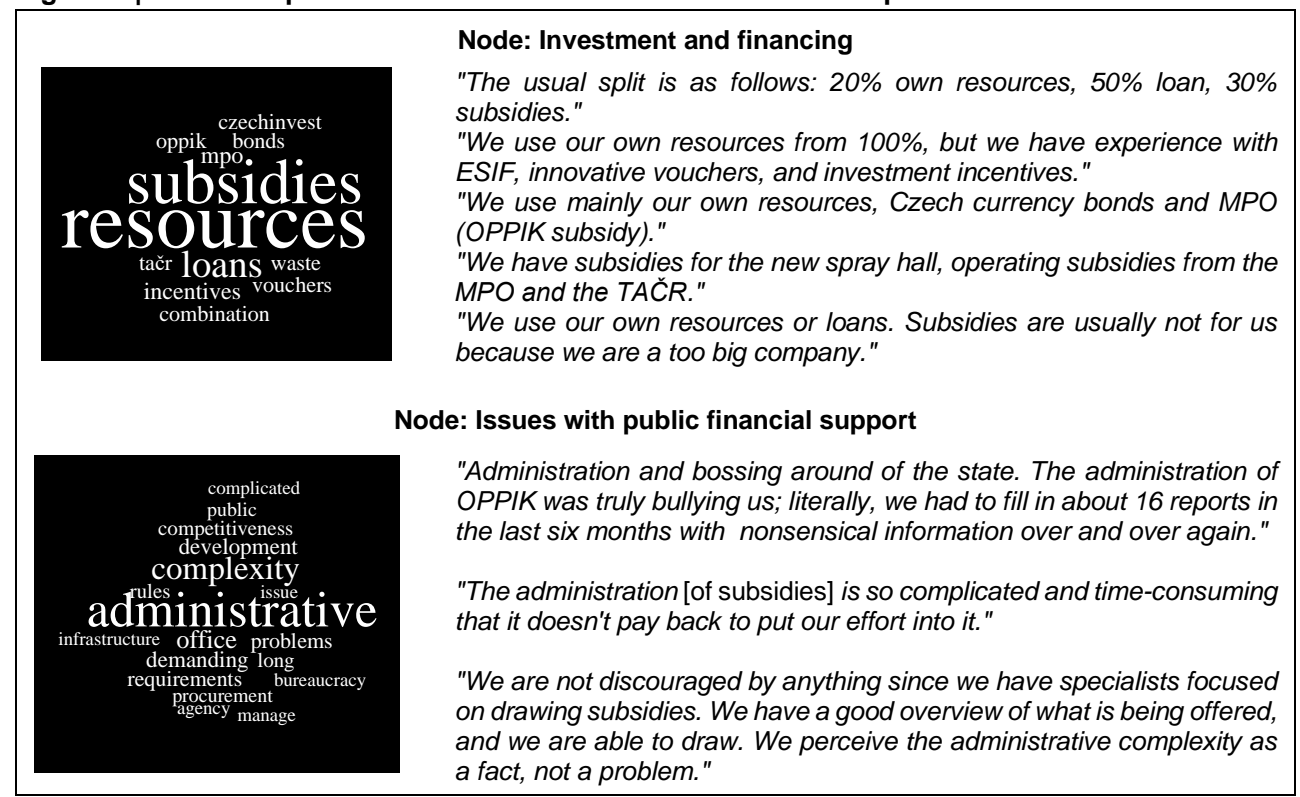

Source: NVivo 12.0 (QSR International)

From the perspective of potential state aid, companies tend to expect and prioritize the fulfilment of the state's role in the sense of building transport and data infrastructure, reforming the education system, and reducing bureaucracy to be better prepared for changes related to Industry 4.0. as demonstrated by the quotes below:

- $\quad$ "The state should address the quality of the workforce and its continuous retraining. It should ensure good transport services and infrastructure, fast internet, e.g., overall quality infrastructure. The provision of subsidies is also appropriate."

- $\quad$ "For us, it is crucial that the state operates 4.0, i.e., that the government especially takes care of the investments in infrastructure, construction of motorways, etc. "

In terms of investment readiness for changes associated with Industry 4.0, company managers expect subsidies and tax incentives from the state. Occasionally the respondents from the Czech companies expressed the need to educate the state officers working with public procurements to consider other criteria than price and, additionally, favour Czech companies in public procurements, especially in strategic industries:

- $\quad$ "It would help us if Czech companies were preferred within the current restrictions in the EU. We are more successful in public procurement abroad than in the Czech Republic. Officials in the Czech Republic are concerned about qualitative criteria, i.e., it is easier for them to choose the lowest price, which is safe, no one can then criticize them. Healthcare is a strategic sector, and the state should favor its 
suppliers. Public procurement contracts are lengthy. There is one ongoing where we are bidding; the preparation has been going on for seven months and is not yet listed. It would help educate state officers to do a "safe" procurement, where the main criterion will not only be the price. Simultaneously, they will not be covered for the decision made based on anything other than pricing criteria in the future. "

The sequence of formating the third research question related to better targeting the state help is shown in Figure 7.

Figure 7 | Formation of RQ3: What are the preferences of different forms of state interventions by different company sizes? Do they prefer area or targeted aid, and if targeted, what are the industries to be supported?
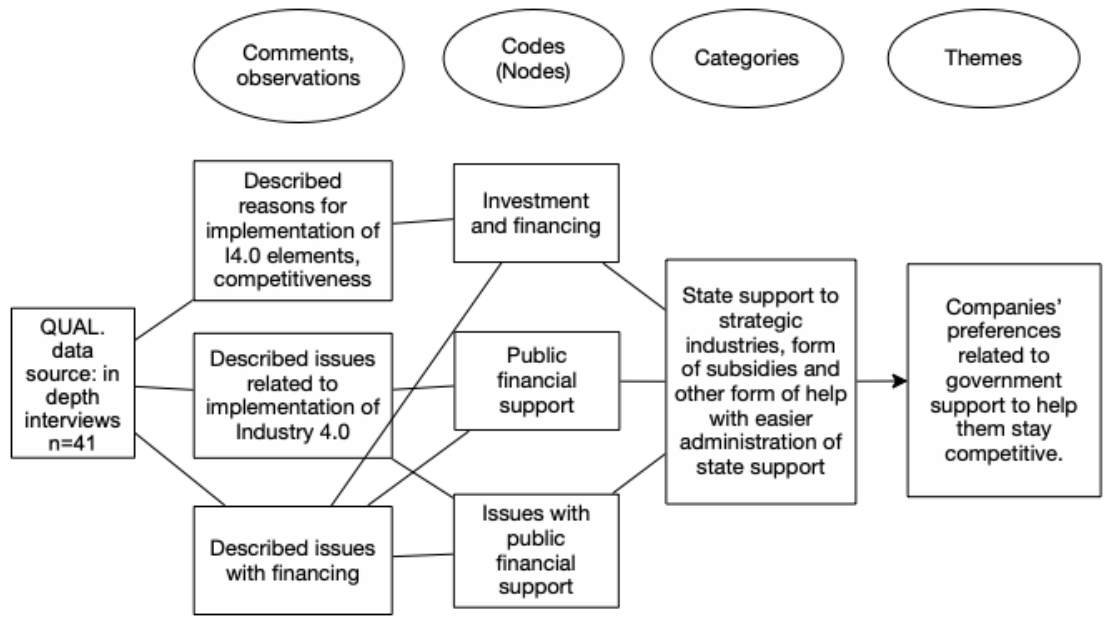

Source: own processing

\section{Findings of the quantitative survey}

\subsection{RQ1: Are there any differences in companies' level of implementation of the elements of Industry 4.0 by industry sectors and by company sizes?}

$85 \%$ of the surveyed companies have already introduced or are planning to introduce any elements of Industry 4.0, which confirms the conclusions of the in-depth interviews. More often, however, these are large companies. $15.1 \%$ of the total sample has not implemented any changes yet and do not plan to do so. For small companies, this number is more significant since $28.3 \%$ have not implemented any changes yet. The most common implemented changes include digital data sharing and transfer $(52.7 \%)$, data analysis (48.6 $\%)$, process changes supported by a suitable information system (37.7\%), and process automation (35.6\%) (Table 2).

There was a statistically significant difference between groups of companies sorted by size, as demonstrated by one-way ANOVA. A Tukey post hoc test showed that the group of large companies (250+) was able to implement the changes statistically more significantly than smaller companies in automatization and robotization of the production $(p=0.001$ for the 
smallest companies and $p=0.005$ for mid-sized companies), in automatization of the processes ( $p=0.008$, resp. $p=0.027)$, 3D printing $(p=0.001$, resp. $p=0.031)$ and in implementation of sensors to different parts of the production $(p=0.017$, resp. $p=0.047$ ). Tools of data analyses and data processing were implemented by large companies significantly more than small enterprises $(p=0.027)$. On the contrary, small companies, more significantly than the group of mid and large-size companies, have not implemented any changes yet $(p=0.009$, resp. $p=0.009)$ (Table 2$)$.

Table 2 | Implementation of the Industry 4.0 elements by company size

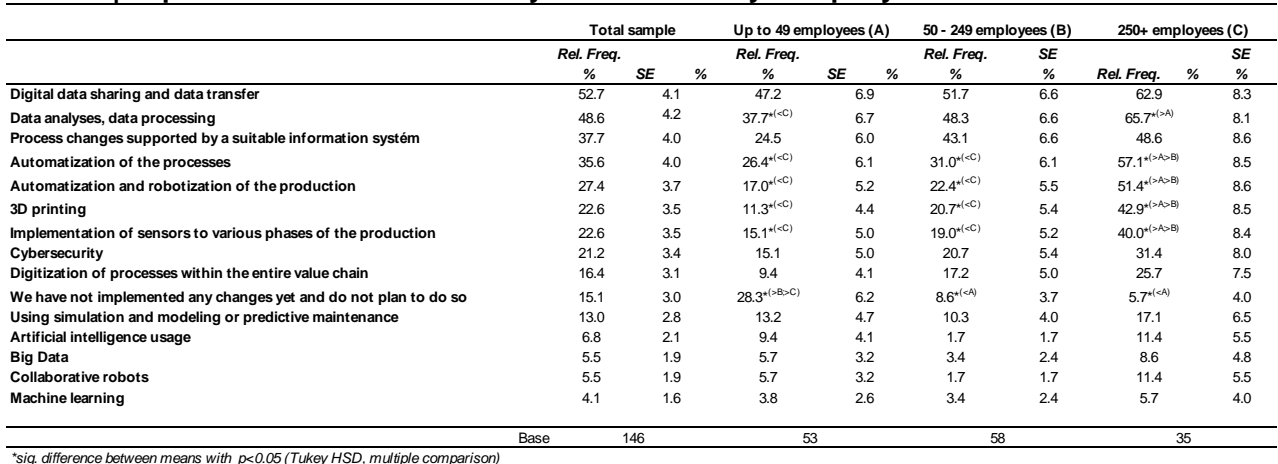

\section{Source: own processing}

The automotive/aerospace, electrotechnical industries, and nanotechnologies are introducing innovative practices more than other sectors, while the healthcare and pharmaceutical sectors (Life Sciences) are lagging behind (Table 3). In the automotive/aerospace industry, the automatization of the processes $(54.5 \%)$ and robotization of the production $(45.5 \%$ ) was top listed by the managers, followed by the implementation of the sensors to various phases of the production (40.9\%) and process changes supported by a suitable information system (40.9\%). A Tukey post hoc test showed that the implementation of (i) automatization of processes and (ii) automatization and robotization of the production was significantly higher amongst the group of automotive/aerospace industry compared to life sciences, the latter to IT ( $p=0.036$ resp. $p=$ 0.01 ) The other sectors remain similar in terms of the \% order of implemented changes of the total sample except for Life Science where the implementation of the cybersecurity items is implemented statistically significantly more $(p=0.015)$ and 3D printing less both compared to Advanced manufacturing ( $p=0.032$ ). 


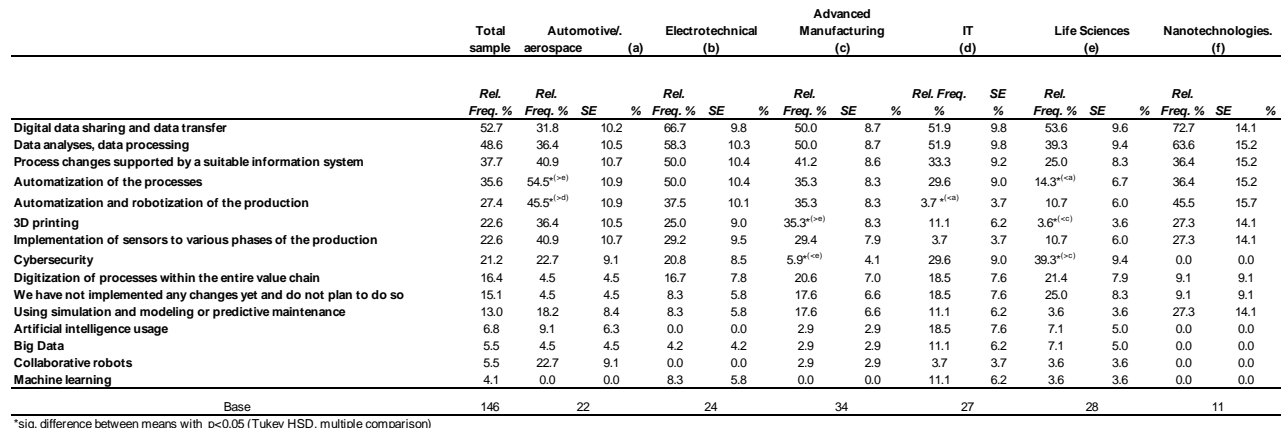

Source: own processing

To conclude RQ1, there are significant differences among the Industry 4.0 elements by both the company sizes and the industry sectors. Small companies (up to 49 employees) have so far statistically significantly adopted fewer components of Industry 4.0 than both bigger groups since more than $1 / 4$ of them did not implement any changes yet, compared to $8.6 \%$ resp. $5.7 \%$ of the other groups. There are significant differences in implementing different tools, with the $250+$ overachieving both smaller company sizes (automatization of processes, automatization, and robotization of the production, 3D printing, implementation of sensors, etc.). Our results confirm the growing implementation level with the company's size, as previously indicated by Vrchota et al. (2020) or Basl and Kopp (2017), while the overall level of implementation has increased due to time and sample differences in data collection. The implementation by industry type is led by automotive, advanced manufacturing, and IT sectors, and there are significant differences in different items and levels of their implementation.

\subsection{RQ2: How is the Industry 4.0 preparedness of the labour force evaluated by the managers, and to what extent is it perceived as a threat? How does it differ by company sizes?}

Across companies, their managers agree that the most significant threat related to employees in implementing the elements of Industry 4.0 is by far the lack of a skilled workforce able to work with new technologies, and all companies have concerns about employees' health among the top three threats (Table 4). The danger of a lack of skilled labour tends to decrease towards the smaller companies, while concern about employees' mental health is growing towards smaller companies. Smaller companies also perceive the local industry's threat due to the more effortless transfer of production to markets with cheaper labour. Large companies seriously consider the threat of a slow induction process or retraining the employees' new technological skills. A Tukey post hoc test showed that this group (250+) considers the threat of slow speed of employees retraining statistically significantly more than both remaining groups ( $p=0.05$ for the smallest companies and $p=0.027$ for mid-sized companies). 
Table 4 | Key threats related to employees and Industry 4.0 changes as perceived by the management

\begin{tabular}{|c|c|c|c|c|c|c|c|c|}
\hline & \multicolumn{2}{|c|}{ Total sample } & \multicolumn{2}{|c|}{$\begin{array}{l}\text { Up to } 49 \\
\text { employees } \\
\text { (A) }\end{array}$} & \multicolumn{2}{|c|}{$\begin{array}{c}50-249 \\
\text { employees. } \\
\text { (B) }\end{array}$} & \multicolumn{2}{|c|}{$\begin{array}{l}\text { employees } \\
\text { (C) }\end{array}$} \\
\hline & $\begin{array}{c}\text { Rel. } \\
\text { Freq. \% }\end{array}$ & $\begin{array}{c}S E \\
\%\end{array}$ & $\begin{array}{c}\text { Rel. } \\
\text { Freq. \% }\end{array}$ & $\begin{array}{l}S E \\
\%\end{array}$ & $\begin{array}{c}\text { Rel. } \\
\text { Freq. \% }\end{array}$ & $\begin{array}{c}S E \\
\%\end{array}$ & $\begin{array}{l}250+ \\
R e l .\end{array}$ & $\begin{array}{l}S E \\
\% \\
\end{array}$ \\
\hline Lack of skilled labor capable of working with new technologies & 67.1 & 3.9 & 54.7 & 6.9 & 74.1 & 5.8 & 74.3 & 7.5 \\
\hline Stress, mental health, resignation of employees & 37.0 & 4.0 & 43.4 & 6.9 & 34.5 & 6.3 & 31.4 & 8.0 \\
\hline The speed of induction/retraining will not correspond to the pace of change to the required qualification & 25.3 & 3.6 & $20.8^{*(<C)}$ & 5.6 & $19.0^{*}(<\mathrm{C})$ & 5.2 & $42.9^{\star(>A ;>B)}$ & 8.5 \\
\hline Threat to local industry due to easier transfer to markets with cheaper labor & 23.3 & 3.5 & 28.3 & 6.2 & 27.6 & 5.9 & 8.6 & 4.8 \\
\hline Surplus of unskilled labor, which does not have a job & 20.5 & 3.4 & 22.6 & 5.8 & 19.0 & 5.2 & 20.0 & 6.9 \\
\hline Strengthen only large companies that have to pay expensive professionals & 19.2 & 3.3 & 22.6 & 5.8 & 17.2 & 5.0 & 17.1 & 6.5 \\
\hline Other & 3.4 & 1.5 & 3.8 & 2.6 & 3.4 & 2.4 & 2.9 & 2.9 \\
\hline
\end{tabular}

${ }^{*}$ sig. difference between means with $\mathrm{p}<0.05$ (Tukey HSD, multiple comparison)

Source: own processing

A qualitative research study by Veile et al. (2019) also uncovered some essential aspects of the introduction of Industry 4.0. With the automation of simple repetitive or physically demanding tasks, the work content has changed in more challenging tasks requiring the skill of decision-making, problem-solving, interdisciplinary competencies, and ICT knowledge. Highlights on employees' roles in the transition process were also brought up (Santos \& Martinho, 2019). As a conclusion of RQ2, the results confirm that the adaptation of personnel to new conditions shouldn't be overlooked as it represents a serious concern for all companies without differences by company size. As also indicated by interpretation of the indepth interviews, the managers see the need to adapt the education system to the changing environment and call for a reform of the education system, including continuous or life-long education of the workforce.

\subsection{RQ3: What are the preferences of different forms of state interventions by different company sizes? Do they prefer area or targeted aid, and if targeted, what are the industries to be supported?}

Regarding state interventions, respondents across all company sizes prefer a transparent business environment to state interventions in any form. Directors of large companies are less against state intervention. With the company's size, the popularity of the subsidies targeted to selected industries and other forms of help for strategic industries is growing (Table 5). A Tukey post hoc test did not show any significant difference amongst means of different groups by company size. Still, it confirmed differences in agreeing with the last statement amongst other sectors - the IT sector managers agree significantly less than electrotechnical $(p=0.013)$, life sciences $(p=0.037)$, and nanotechnologies $(p=0.039)$ that the state should intervene behind selected industries (Table 6). 
Table 5 | Preferences of various approaches to the state interventions by different company sizes

\begin{tabular}{|c|c|c|c|c|c|c|c|c|}
\hline & \multicolumn{2}{|c|}{$\begin{array}{c}\text { Total } \\
\text { sample }\end{array}$} & \multicolumn{2}{|c|}{$\begin{array}{l}\text { Up to } 49 \\
\text { employees } \\
\text { (A) }\end{array}$} & \multicolumn{2}{|c|}{$\begin{array}{l}50 \text { - } 249 \\
\text { employees. } \\
\text { (B) }\end{array}$} & \multicolumn{2}{|c|}{$\begin{array}{l}250+ \\
\text { employees. } \\
\text { (C) }\end{array}$} \\
\hline & Mean ${ }^{\star}$ & SE & Mean ${ }^{\star}$ & SE & Mean ${ }^{\star}$ & SE & Mean ${ }^{\star}$ & SE \\
\hline $\begin{array}{l}\text { The state should set up a transparent business environment and not further intervene in it } \\
\text { in the form of subsidies, tax relief or otherwise }\end{array}$ & 3.18 & 0.07 & 3.21 & 0.12 & 3.22 & 0.12 & 3.09 & 0.14 \\
\hline $\begin{array}{l}\text { The state should set up a transparent business environment and actively intervene in it in } \\
\text { the form of area subsidies (regardless of industry sector), tax relieves or otherwise }\end{array}$ & 1.75 & 0.07 & 1.70 & 0.11 & 1.78 & 0.10 & 1.77 & 0.14 \\
\hline $\begin{array}{l}\text { The state should set up a transparent business environment and further actively intervene } \\
\text { in it in the form of selected industry subsidies, taxes relief or otherwise targeted to state } \\
\text { strategic industries }\end{array}$ & 2.55 & 0.08 & 2.26 & 0.14 & 2.67 & 0.13 & 2.77 & 0.17 \\
\hline Base & 146 & & 53 & & 58 & & 35 & \\
\hline
\end{tabular}

*scale 1-4; 4 fully agree

Source: own processing

Table 6 | Preferences of different approaches to state interventions by various industries

\begin{tabular}{|c|c|c|c|c|c|c|c|c|c|c|c|c|c|c|}
\hline & \multicolumn{2}{|c|}{ Total sample } & \multicolumn{2}{|c|}{$\begin{array}{l}\text { Automotive } \\
\text { /aerospace } \\
\text { (a) }\end{array}$} & \multicolumn{2}{|c|}{$\begin{array}{l}\text { Electrotechnical } \\
\text { (b) }\end{array}$} & \multicolumn{2}{|c|}{$\begin{array}{l}\text { Advanced } \\
\text { Manufacturing } \\
\text { (c) }\end{array}$} & \multicolumn{2}{|c|}{$\begin{array}{l}\text { IT } \\
\text { (d) }\end{array}$} & \multicolumn{2}{|c|}{$\begin{array}{l}\text { Life Sciences. } \\
\text { (e) }\end{array}$} & \multicolumn{2}{|c|}{$\begin{array}{c}\text { Nanotechnologies } \\
(f)\end{array}$} \\
\hline & Mean ${ }^{* *}$ & SE & Mean** & SE & Mean ${ }^{* *}$ & SE & Mean** & SE & Mean ${ }^{\text {** }}$ & $\mathrm{SE}$ & Mean** & SE & Mean ${ }^{\text {** }}$ & SE \\
\hline $\begin{array}{l}\text { The state should set up a transparent business environment and not } \\
\text { further intervene in it in the form of subsidies, tax relief or otherwise }\end{array}$ & 3.18 & 0.07 & 3.05 & 0.19 & 3.25 & 0.17 & 3.32 & 0.14 & 3.33 & 0.17 & 3.18 & 0.16 & 2.55 & 0.37 \\
\hline $\begin{array}{l}\text { The state should set up a transparent business environment and } \\
\text { actively intervene in it in the form of area subsidies (regardless of } \\
\text { industry sector), tax relieves or otherwise }\end{array}$ & 1.75 & 0.07 & 1.95 & 0.14 & 1.67 & 0.14 & 1.68 & 0.14 & 1.74 & 0.17 & 1.82 & 0.15 & 1.55 & 0.25 \\
\hline $\begin{array}{l}\text { The state should set up a transparent business environment and further } \\
\text { actively intervene in it in the form of selected industry subsidies, taxes } \\
\text { relief or otherwise targeted to state strategic industries }\end{array}$ & 2.55 & 0.08 & 2.59 & 0.21 & $2.90^{(+\Delta d)}$ & 0.19 & 2.44 & 0.18 & 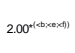 & 0.17 & $2.81^{(:(x))}$ & 0.20 & $3.01^{(\neq ⿱ 亠 乂 ⿰ 丿)}$ & 0.19 \\
\hline Base & & & & & 24 & & & & 27 & & 2 & & 1 & \\
\hline
\end{tabular}

Source: own processing

Respondents who expressed agreement with the statements that the state should set up a transparent business environment and actively intervene in it in the form of selected industry subsidies, taxes relief, or otherwise $(\mathrm{N}=87)$ were asked about their preferences regarding different forms of state interventions or any other help from the government (Table 7). Easier administration leads amongst the tools that companies would welcome. More than the others, small companies would appreciate interest-free loans and adjustment of state tenders in favor of Czech companies. Large companies are most interested in supporting $R \& D$, declare the most significant importance of education reform, and greater cooperation between companies and schools. Comparing the means between the three company sizes, a Tukey post hoc test showed significant differences in preferences of the investment subsidies in the group of smallest vs. the most prominent companies $(p=0.022)$, confirming that investment subsidies are significantly more appreciated by the managers of the $250+$ companies (Table 7). 
Table 7 | State interventions preferences amongst Czech companies

\begin{tabular}{|c|c|c|c|c|c|c|c|c|c|}
\hline & & \multicolumn{2}{|c|}{ Base } & \multicolumn{2}{|c|}{$\begin{array}{l}\text { Up to } 49 \text { employees } \\
\text { (A) }\end{array}$} & \multicolumn{2}{|c|}{$\begin{array}{l}50 \text { - } 249 \text { employees } \\
\text { (B) }\end{array}$} & \multicolumn{2}{|c|}{$\begin{array}{l}250+\text { employees } \\
\text { (C) }\end{array}$} \\
\hline & & Mean $^{\star}$ & $\mathrm{SE}$ & Mean ${ }^{*}$ & $\mathrm{SE}$ & Mean ${ }^{\star}$ & $\mathrm{SE}$ & Mean $^{\star}$ & $\mathrm{SE}$ \\
\hline Easier administration (smaller requirements of the tax offices) & & 3.59 & 0.08 & 3.68 & 0.14 & 3.68 & 0.11 & 3.36 & 0.19 \\
\hline Education reform (adaptation of study fields) & & 3.49 & 0.08 & 3.25 & 0.20 & 3.56 & 0.09 & 3.68 & 0.13 \\
\hline Intensified cooperation between schools and companies & & 3.34 & 0.09 & 3.14 & 0.19 & 3.35 & 0.13 & 3.56 & 0.12 \\
\hline Subsidies for R\&D & & 3.22 & 0.10 & 3.04 & 0.20 & 3.24 & 0.16 & 3.40 & 0.16 \\
\hline Greater tax relief for R\&D & & 3.16 & 0.10 & 3.04 & 0.19 & 3.06 & 0.16 & 3.44 & 0.15 \\
\hline Subsidies for employee training & & 3.05 & 0.09 & 2.89 & 0.19 & 2.97 & 0.14 & 3.32 & 0.13 \\
\hline Subsidies for training of trainees (apprentices / students) & & 3.00 & 0.10 & 2.82 & 0.21 & 3.03 & 0.15 & 3.16 & 0.15 \\
\hline Awareness of new national programs in technologies & & 2.98 & 0.08 & 3.04 & 0.16 & 2.82 & 0.13 & 3.12 & 0.15 \\
\hline Soft loans & & 2.84 & 0.10 & 2.82 & 0.19 & 2.79 & 0.16 & 2.92 & 0.18 \\
\hline Investment subsidies & & 2.83 & 0.10 & $2.51^{\star \star(<C)}$ & 0.16 & 2.79 & 0.17 & $3.22^{\star \star(>A)}$ & 0.15 \\
\hline Interest free loans & & 2.79 & 0.10 & 2.89 & 0.18 & 2.82 & 0.17 & 2.64 & 0.19 \\
\hline Subsidies for a new job & & 2.60 & 0.10 & 2.50 & 0.18 & 2.62 & 0.17 & 2.68 & 0.18 \\
\hline SEED funds or a similar concept & & 2.53 & 0.10 & 2.68 & 0.16 & 2.56 & 0.15 & 2.32 & 0.18 \\
\hline $\begin{array}{l}\text { Adjustment of tenders in favor of Czech companies (public } \\
\text { procurement) }\end{array}$ & & 2.52 & 0.11 & 2.79 & 0.20 & 2.35 & 0.17 & 2.44 & 0.19 \\
\hline Subsidies for expansion abroad & & 2.43 & 0.10 & 2.43 & 0.18 & 2.29 & 0.16 & 2.60 & 0.20 \\
\hline & Base & 87 & & 28 & & 34 & & 25 & \\
\hline
\end{tabular}

"scale 1-4; 4 fully agree

${ }^{* *}$ sig. difference between means with $p<0.05$ (Tukey HSD, multiple comparison)

\section{Source: own processing}

The group of companies $(\mathrm{N}=80)$, who agreed with the statement that the state support should be targeted to selected strategic industries, were asked to name strategic sectors that the government should selectively support. The top-listed sectors are education, research \& development, agriculture/sustainable agriculture, energy, healthcare, manufacturing, and ecology/environment protection (Chart 1).

\section{Chart 1 | Strategic industries for targeted government support (management preferences)}

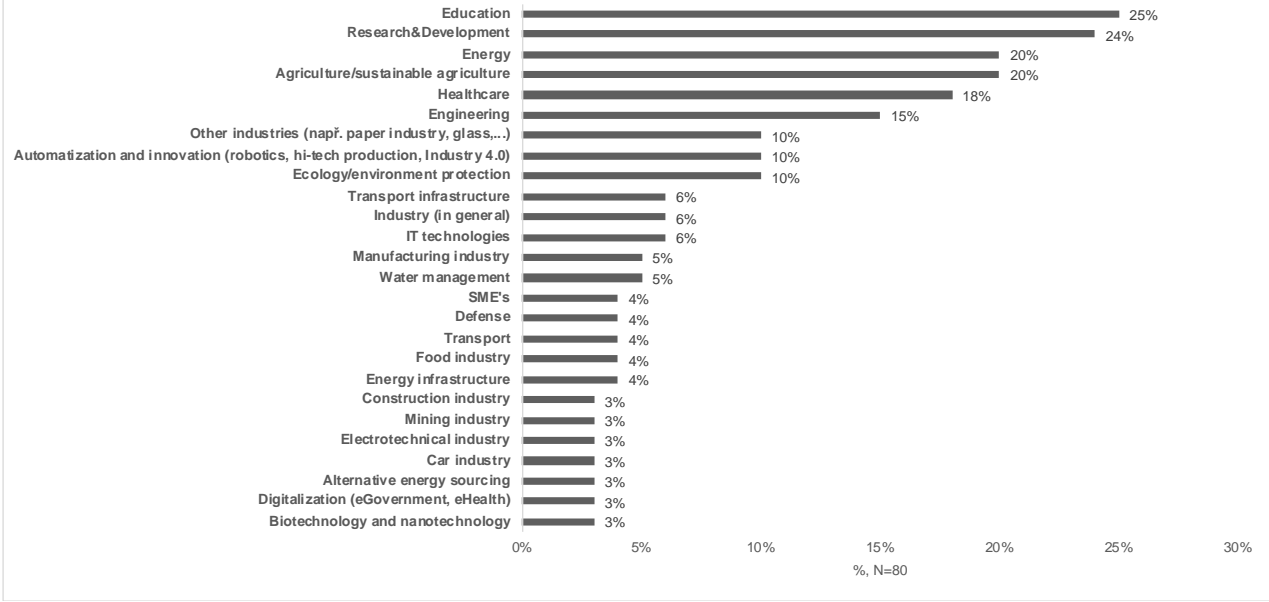

Source: own processing

To conclude RQ3 related to preferences of different forms of state interventions, the respondents expressed more substantial agreement with the statement that the state should set up a transparent business environment and not further intervene in it in the form of subsidies, tax relief, or otherwise. Despite the positive approach to the subsidies in the indepth interviews and the high proportion of the companies with experiences with the state or European subsidies in the quantitative survey, the respondents would appreciate when the 
state does not burden the companies with the additional administration. As one of the preferences in terms of the strategic industries and one of the items indicated as state aid's preferred form, education resonates through the current research results. The company management perceives it as an essential step for future competitiveness, and it is also supported by Marešová et al. (2018) and Sung (2018). Despite the education was one part of the Czech government's National Research and Innovation Strategy for Intelligent Specialization of the Czech Republic (National RIS3 Strategy) 2014 - 2020 (updated 2018) (MPO CR, 2018), the broad education reform has not been addressed yet. The actions related to education and human resources in RIS3 strategy are fragmented to addressing just current issues rather than formed as a strategic outlook with a vision related to profound reform of the structure of the Czech education system.

\section{Joint display of results of mixed research}

As indicated in the methodology part, Figure 8 provides the joint display streamlining codesto-theory sequences of the qualitative interviews resulting in mixed insights from both quantitative and qualitative data.

The initial comments grouped in nodes formed the subsequent categories and themes as the base for the research questions addressed by the quantitative survey. Mixed insights are linked to both parts of the data collection and highlight the present mixed research study's key findings.

Figure 8 | Summary of results of mixed research

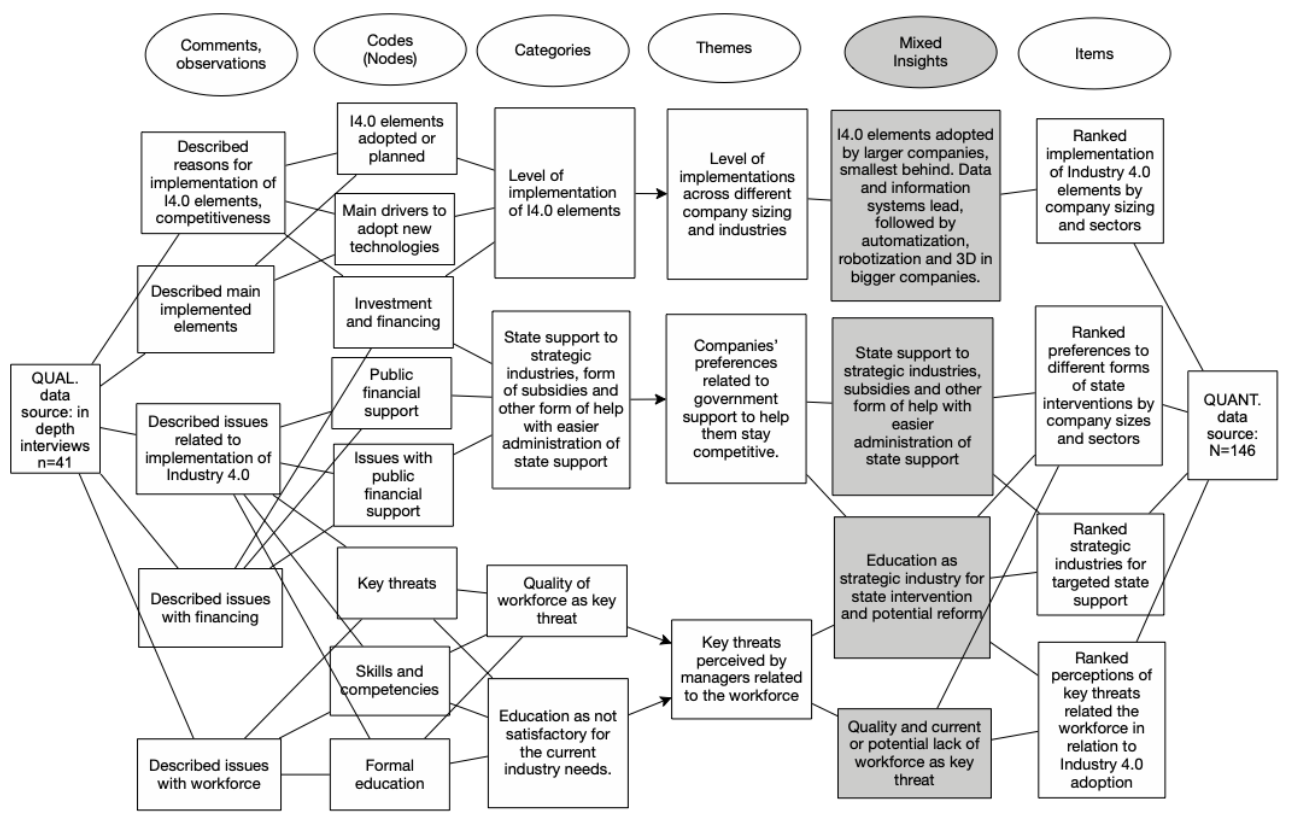

Source: NVivo 12.0 (QSR International) 


\section{Discussion}

The literature review suggested heterogeneity of research results related to the implementation of the Industry 4.0 elements and the importance of the state aid targeted to different company sizing and industries. Therefore, the observation of top managers' opinions to understand better what they find essential for their future business development is important.

Findings of the present study indicate that most of the sample have already introduced or are planning to introduce some elements of Industry 4.0. The implementation level grows with the company's size, as supported by Vrchota et al. (2020). Basl and Kopp (2017), on the contrary, identified much lower preparedness of the industry as such, which could be explained by the difference in data collection timing and potentially demonstrates the dynamics of the business in changes adoption. The automotive/aerospace, electrotechnical industries, and nanotechnologies are introducing innovative practices more than other sectors, while the IT sector is exceeding the others in implementing artificial intelligence.

Lack of skilled employees working with advanced technologies is perceived as the most potent threat related to employees while implementing the elements of Industry 4.0, especially among larger companies. This fear is linked to observed issues with the formal education system and, more importantly, to respondent's prioritization of the education sphere as one of the strategic industries for future state interventions (besides R\&D, energy, agriculture and healthcare). The educational system should become more responsive to the needs of the industry, as indicated by Marešová et al. (2018), Sung (2018), whereas the new capabilities of the workforce in relation to new technological challenges were also suggested by Veile et al. (2019).

Most respondents agreed that a transparent business environment was preferred to different state interventions. Amongst the state interventions or other tools to help business, the respondents expressed a strong call for easier administration, especially related to the bureaucracy needs from the tax offices, in line with the findings of Karo and Kattel (2015), who also highlighted the need for more flexibility in the procedures. The contribution of subsidies to the economy can be distorted by the fact that many companies apply for a subsidy just because their competitors do so, they have to use in a given time, and therefore the company's investment plans are disturbed by it, especially when adjustments need to be adapted to fit the criteria for allocation of a subsidy. Respondents appreciate when the state simplifies administration related to subsidies or other forms of state aid. The administration represents a burden that might be together with limited management capacity discouraging from subsidy application as supported by Barbosa and Silva (2018).

Results further indicate that large companies favor state help in financing the investment behind R\&D, as opposed to Aiello et al. (2019), who argue in favor of R\&D policies for micro and small enterprises that face financial constraints in financing innovative activities. Large firms are less sensitive to all forms of barriers (including the administration burden), as also investigated by Busome et al. (2014) because they have gained experience over the years and created critical and facilitating networks.

The need to address the education system changes is considered here as an implication targeted to government authorities. Respondents of both the qualitative and quantitative parts of the current study express the need to adapt the education system to produce a labour 
force ready for the changes related to Industry 4.0. Education was also top listed on the respondent's list of strategic industries supported by the state. The World Economic ' 'Forum's Platform for Shaping the Future of the New Economy and Society initiated a move towards Education 4.0 and invited Ministers of Education and other stakeholders to join the Forum platform to define and implement a plan to transition to Education 4.0. (World Economic Forum, 2020). E\&Y (2018) also stressed various trends such as the advancement of technology, growing needs for competency-based skills, the increasing number of nontraditional learners, and consequently a change from traditional student learners to lifelong education. The topic of bringing Industry 4.0 to Czech schools should be further explored and addressed.

\section{Conclusions, implications, and limitations}

The current research findings suggest addressing administration simplification, business environment transparency, and reform of the Czech Republic's education system.

Results revealed the elements currently adopted by Czech companies most frequently, e.g., data sharing/processing, automatization, robotization, with marked differences based on company size and industry sector. Additionally, it suggested intense penetration of local and European subsidies while highlighting the substantial administrative burdens when drawing it. Quality of the projects should be the decisive factor for the authorities without complex and lengthy procedures since the simple and intuitive access to public support allows companies to focus on doing business. Large companies are usually more open to various subsidizing schemes. SMEs, however, would welcome smaller and better-targeted grants, especially if they cannot afford to pay a specialized workforce to deal with subsidies. Thus, it is clear that government intervention should focus more on smaller and well-targeted schemes to promote agile SMEs. For this segment, personal approach and consulting are crucial as well. Both advocate the existence of specialized trade and investment promoting agencies with an active presence in the regions.

Companies expect further investment in the elements related to Industry 4.0 even more investment intensive than those already implemented. At the same time, they realize that without doing so, they would lose towards competition. Losing competitiveness and adaptation of the workforce to new technologies are perceived as a key threat. Even though agile companies would prefer minimum government intervention besides setting up a transparent and fair business environment, existing subsidies do force firms to use government support too. Government schemes should follow a recent trend of smart specialization and build upon existing potential and foresight to eliminate their distortive effect on the market.

Notably, the results suggest enhancement of the transparent business environment without intervention in the form of subsidies, tax relief, or otherwise because in many cases, the companies use it just because without doing so, they would lose competitive advantage since the competition is using it. Importantly, formal education reform resonates through the current research results. The company management perceives Education 4.0 to the current Czech education system as one of the strategic priorities that the state should focus on besides building necessary traffic and data infrastructure, and target state help selectively to named industries (R\&D, agriculture, energy, healthcare). Labour force qualification is the biggest challenge companies face when implementing Industry 4.0; this applies the most to 
secondary education and vocational training. While technology gradually outplaces the least educated segment, operators and well-trained experts are missing in the respective regions. For all education levels, competencies and soft skills (loyalty, teamwork, creativity, critical thinking) are ever more important in the new positions and missing the most. To address this deficit, a profound reform of the education system, as well as teacher's training, is required. According to the respondents, it is more pressing than the increase in technical skills as often promoted by the current Czech education reform materials.

In terms of the limitations of the present study, it should be noticed that besides the occurring common biases of the qualitative data collection and interpretation, the qualitative findings cannot be extended to the whole industry with the same degree of certainty. Additionally, the present study's quantitative stage sample was not large enough to yield robust results and represent all industrial sectors in the Czech Republic. Therefore, care should be exercised when generalizing these findings to other industry sectors.

\section{Acknowledgement}

This paper was prepared as one of the outcomes of the project of the Faculty of International Relations of the Prague University of Economics and Business and Technological Agency of the Czech Republic (TAČR) registered by TAČR under TL02000451.

\section{References}

Aiello, F., Albanese, G., \& Piselli, P. (2019). Good value for public money? The case of R\&D policy. Journal of Policy Modeling, 41(6), 1057-1076. https://doi.org/10.1016/j.jpolmod.2019.02.006

Anaya, L., Dulaimi, M., \& Abdallah, S. (2015). An investigation into the role of enterprise information systems in enabling business innovation. Business Process Management Journal, 21(4), 771-790. https://doi.org/10.1108/BPMJ-11-2014-0108

Ayşe Göksu, Ö., Ergün, E., Ammari, D., \& Görener, A. (2018). How Industry 4.0 Changes Business: A Commercial Perspective. International Journal of Commerce and Finance, 4(1), 84-95.

Barbosa, N., \& Silva, F. (2018). Public financial support and firm-specific characteristics: evidence from Portugal. European Planning Studies, 670-686.

https://doi.org/10.1080/09654313.2017.1417358

Basl, J., \& Kopp, J. (2017). Study of the Readiness of Czech Companies to the Industry 4.0. Journal of Systems Integration, 8(3), 40-45. https://doi.org/10.20470/jsi.v8i3.313

Bryman, A. (2006). Integrating quantitative and qualitative research: how is it done? Qualitative Research, 6(1), 97-113. https://doi.org/10.1177/1468794106058877

Buigues, P.-A., \& Sekkat, K. (2011). Public Subsidies to Business: An International Comparison. Journal of Industry, Competition and Trade, 11(1), 1-24. https://doi.org/10.1007/s10842-0100074-1

Busom, I., Corchuelo, B., \& Martínez-Ros, E. (2014). Tax incentives... or subsidies for business R\&D? Small Business Economics, 43, 571-596. https://doi.org/10.1007/s11187-014-9569-1

Carvalho, A. (2011). Why are tax incentives increasingly used to promote private R\&D? Working Paper (4).

Confederation of Industry of the Czech Republic. (2019). Výsledky průzkumu SP ČR o zavádění Prümyslu 4.0 ve firmách. Retrieved September 8,2020 , from https://www.spcr.cz/aktivity/zhospodarske-politiky/13110-vysledky-pruzkumu-sp-cr-o-zavadeni-prumyslu-4-0-ve-firmach 
Creswell, J. W., Clark, V. P., Gutmann, M. L., \& Hanson, W. E. (2003). Advanced Mixed Methods Research Designs. In A. Tashakkori, \& C. Teddlie, Handbook of mixed methods in social and behavioral research (pp. 209-240). Thousand Oaks, CA: SAGE.

Czarnitzki, D., \& Delanote, J. (2015). R\&D policies for young SMEs: input and output effects. Small Business Economics, 45, 465-485. https://doi.org/10.1007/s11187-015-9661-1

Czech Statistical Office. (2018). V IT je nedostatek odborníků. Retrieved September 9, 2020, from https://www.czso.cz/csu/czso/v-it-je-nedostatek-odborniku

Czech Statistical Office. (2019). Ukazatele výzkumu a vývoje - 2018. Retrieved September 9, 2020, from https://www.czso.cz/csu/czso/ukazatele-vyzkumu-a-vyvoje-2018

Czech Statistical Office. (2020). Innovation Activities of Enterprises - 2016 - 2018. Retrieved September 9, 2020, from https://www.czso.cz/csu/czso/inovacni-aktivity-podniku-20162018

Czechlnvest. (2020). Czechlnvest - Business and Investment Development Agency. Retrieved August 3, 2020, from https://www.czechinvest.org/en/About-Czechlnvest/About-Us

Čadil, J., Mirošník, K., \& Petkovová, L. (2016). Impact of R\&D Subsidies on Enterprise Performance in the Czech Republic. Society and Economy, 387-398. https://doi.org/10.1556/204.2016.38.3.7

Deloitte. (2018). The Fourth Industrial Revolution Is Here - Are You Ready? Retrieved September 20, 2020, from https://www2.deloitte.com/za/en/pages/consumer-industrialproducts/articles/industry-4-0--are-you-ready.html

Dvouletý, O., \& Blažková, I. (2019). The Impact of Public Grants on Firm-Level Productivity: Findings from the Czech Food Industry. Sustainability, 11(5), 552. https://doi.org/10.3390/su11020552

E\&Y. (2018). University of the Future. Bringing Education 4.0 to Life. Retrieved November 29, 2019, from https://www.ey.com/Publication/vwLUAssets/ey-university-of-the-future/\$File/eyuniversity-of-the-future.pdf

European Commission. (2017). R\&D tax incentives. How to make them most effective? Retrieved September 20, 2020, from https://rio.jrc.ec.europa.eu/sites/default/files/report/Tax_incentives_KI-04-17-666-EN-N.pdf

European Commission. (2019). Competition. Retrieved September 20, 2020, from https://ec.europa.eu/competition/state_aid/overview/index_en.html

European Commission. (2020a). A New Industrial Strategy for Europe. Retrieved September 18, 2020, from https://eur-lex.europa.eu/legalcontent/EN/TXT/PDF/?uri=CELEX:52020DC0102\&from=EN

European Commission. (2020b). European innovation scoreboard. Retrieved September 18, 2020, from https://ec.europa.eu/growth/industry/policy/innovation/scoreboards_en

Fetters, M. D., Curry, L. A., \& Creswell, J. W. (2013). Achieving Integration in MixedMethods DesignsPrinciples and Practices. Health Services Research, pp. 2134-2156. https://doi.org/10.1111/1475-6773.12117

Greco, M., Grimaldi, M., \& Cricelli, L. (2017). Hitting the nail on the head: Exploring the relationship between public subsidies and open innovation efficiency. Technological Forecasting\&Social Change(118), 213-225. https://doi.org/10.1016/j.techfore.2017.02.022

Hermann, M., Pentek, T., \& Otto, B. (2016). Design Principles for Industrie 4.0 Scenarios. 2016 49th Hawaii International Conference on System Sciences (HICSS) (pp. 3928-3937). Piscataway: IEEE. https://doi.org/ HYPERLINK "https://doi.org/10.1109/HICSS.2016.488" It "_blank" 10.1109/HICSS.2016.488 
Kang, K.-N., \& Park, H. (2011). Influence of government R\&D support and inter-firmcollaborationson innovation in Korean biotechnology SMEs. Technovation, 32(1), 68-78. https://doi.org/10.1016/j.technovation.2011.08.004

Karhunen, H., \& Huovari, J. (2015). R\&D subsidies and productivity in SMEs. Small Business Economics, 45, 805-823. https://doi.org/10.1007/s11187-015-9658-9

Karo, E., \& Kattel, R. (2015, Vol. 18, No. 2, 172-187). Economic development and evolving state capacities in Central and Eastern Europe: Can "smart" specialization" make a difference? Journal of Economic Policy Reform, 172-187. https://doi.org/10.1080/17487870.2015.1009068

Marešová, P., Soukal, I., Svobodová, L., Hedvičáková, M., \& Javanmardi, E. (2018). Consequences of Industry 4.0 in Business and Economics. Economies, 6(3), 1-14. https://doi.org/10.3390/economies6030046

Maroušek, J., Hašková, S., Zeman, R., Váchal, J., \& Vaníčková, R. (2015, 17, pp. 549-554). Assessing the implications of EU subsidy policy on renewable energy in Czech Republic. Clean Techn Environ Policy, 17, 549-554. https://doi.org/10.1007/s10098-014-0800-1

Mewes, L., \& Broekel, T. (2020). Subsidized to change? The impact of R\&D policy on regional technological diversification. The Annals of Regional Science(65), pp. 221-252. https://doi.org/10.1007/s00168-020-00981-9

Minford, L., \& Meenagh, D. (2019). Testing a model of UK growth: A role for R\&D subsidies. Economic Modelling, 82, 152-167. https://doi.org/10.1016/j.econmod.2019.01.002

MPO CR. (2018). National Research and Innovation Strategy for Intelligent Specialization of the Czech Republic (National RIS3 Strategy) 2014 - 2020 (update 2018). Retrieved October 30, 2020, from https://www.dataplan.info/img_upload/7bdb1584e3b8a53d337518d988763f8d/narodni_ris3_ strategie_aktualizace_2018.pdf

Onwuegbuzie, A. J., Bustamante, R. M., \& Nelson, J. A. (2010). Mixed Research as a Tool for Developing Quantitative Instruments. Journal of Mixed Methods Research, 4(1), pp. 56-78. https://doi.org/10.1177/1558689809355805

Philbeck, T., \& Davis, N. (2019). The Fourth Industrial Revolution: Shaping A New Era. Journal of International Affairs, 72(1), 17-22.

Ravšelj, D., \& Aristovnik, A. (2018). The Impact of Private Research and Development Expenditures and Tax Incentives on Sustainable Corporate Growth in Selected OECD Countries. Sustainability. https://doi.org/10.3390/su10072304

Romijn, H., \& Albaladejo, M. (2002). Determinants of innovation capability in small electronics and software firms in southeast England. Research Policy, 31, 1053-1067. https://doi.org/10.1016/S0048-7333(01)00176-7

Schutt, K. R. (2015). Qualitative Data Analyses. In K. R. Schutt, Investigating the Social World. The Process and Practice of Research. SAGE Publications, Inc.

Santos, R. C., \& Martinho, J. L. (2019). An Industry 4.0 maturity model proposal. Journal of Manufacturing Technology Management. https://doi-org.ezproxy.lib.cas.cz/10.1108/JMTM09-2018-0284

Sekaran, U., \& Bougie, R. (2009). Research methods for Business (Vol. 5th Edition). Chichester, West Sussex, United Kingdom: John Wiley \& Sons Ltd.

Sreejesh, S., \& Mohapatra, S. (2014). Mixed Method Research Design. Springer. 
Srholec, M. (2014). Cooperation and Innovative Performance of Firms: Panel Data Evidence from the Czech Republic, Norway and the UK. J Knowl Econ, 5, pp. 133-155.

https://doi.org/10.1007/s13132-013-0175-2

Sung, T. (2018). Industry 4.0: A Korea Perspective. Technological Forecasting and Social Change, 132, 40-45. https://doi.org/10.1016/j.techfore.2017.11.005

Tunali, C. B., \& Fidrmuc, J. (2015). State Aid Policy in the European Union. Journal of Common Market Studies, 53(5), 1143-1162. http://dx.doi.org/10.1111/jcms.12247

Veile, J. W., Kiel, D., Müller, J. M., \& Voigt, K.-I. (2019). Lessons learned from Industry 4.0 implementation in the German manufacturing industry. Journal of Manufacturing Technology Management. https://doi.org/10.1108/JMTM-08-2018-0270

Vrchota, J., Vlčková, M., \& Frantíková, Z. (2020). Division of Enterprises and their Management Strategies in Relation to Industry 4.0. Central European Business Review, 9(4), 27-44. https://doi.org/10.18267/j.cebr.243

World Economic Forum. (2020). Schools of the Future Defining New Models of Education for the Fourth Industrial Revolution. Retrieved January 18, 2021, from http://www3.weforum.org/docs/WEF_Schools_of_the_Future_Report_2019.pdf

The research paper passed the review process. | Received: November 2, 2020; Revised: March 12, 2021; Accepted: April 2, 2021; Pre-published online: June 19, 2021; Published in the regular issue: December 5, 2021. 
Appendix 1 | Detailed description of the sample for the in-depth interviews.

\begin{tabular}{|c|c|c|c|c|c|c|c|c|c|}
\hline & Subject of business & $\begin{array}{l}\text { Interview } \\
\text { date }\end{array}$ & $\begin{array}{l}\text { Respondent's } \\
\text { job }\end{array}$ & Region & NACE & $\begin{array}{l}\text { No. of } \\
\text { empl. }\end{array}$ & \begin{tabular}{|l|} 
Absolute \\
expenditure \\
on research \\
and \\
development \\
(LY) (Czk)
\end{tabular} & \begin{tabular}{|l|} 
Relative \\
expenditure \\
on research \\
and \\
development
\end{tabular} & $\begin{array}{l}\text { R\&D expenditure } \\
\text { type }\end{array}$ \\
\hline 1 & $\begin{array}{l}\text { Innovation and technology for market entry, then sale in the form of } \\
\text { licenses }\end{array}$ & 5.11 .2019 & BOM member & Prague & 7219 & 20 & NA & $90 \%$ & \begin{tabular}{|l|} 
Investment \\
expenditures
\end{tabular} \\
\hline 2 & Production of bicycles and fishing equipment & 11.11 .2019 & \begin{tabular}{|l} 
Finance/ \\
Purchasing \\
manager
\end{tabular} & Moravskoslezský & 3092 & 644 & NA & NA & NA \\
\hline 3 & $\begin{array}{l}\text { Production of mining machinery and equipment intended for the } \\
\text { transport of materials }\end{array}$ & 12.11 .2019 & Sales director & Moravskoslezský & 3020 & 280 & 40-50 Mio & $\operatorname{cca} 3,2 \%$ & Wages, material \\
\hline 4 & Production of kitchen accessories & 12.11 .2019 & CEO & Moravskoslezský & 2751 & 22 & 6 Mio & $7-8 \%$ & $\begin{array}{l}\text { Investment } \\
\text { expenditures }\end{array}$ \\
\hline 5 & $\begin{array}{l}\text { Manufacture of headlamps, rear lamps and electronics for } \\
\text { passenger cars }\end{array}$ & 14.11 .2019 & $\begin{array}{l}\text { Technical Center } \\
\text { Director }\end{array}$ & Olomoucký & 27400 & 3100 & NA & NA & NA \\
\hline 6 & $\begin{array}{l}\text { Production of precision optics and mechanics for components of } \\
\text { optoelectronic and optomechanical systems }\end{array}$ & 15.11 .2019 & $\begin{array}{l}\text { Director Global } \\
\text { Operations } \\
\end{array}$ & Olomoucký & $26700 ; 256$ & 2391 & NA & up to $10 \%$ & Wages \\
\hline 7 & Development and production of urodynamic devices & 15.11 .2019 & \begin{tabular}{|l} 
Managing \\
Director
\end{tabular} & Olomoucký & 325 & 15 & $\begin{array}{l}27 \text { Mio (last } 3 \\
\text { years) }\end{array}$ & & Wages \\
\hline 8 & Automotive & 28.11 .2019 & $\begin{array}{l}\text { Managing } \\
\text { Director }\end{array}$ & Karlovarský & 2572 & 1900 & $\begin{array}{l}\text { differs each } \\
\text { year }\end{array}$ & & \begin{tabular}{|l} 
Equipment and \\
machinery
\end{tabular} \\
\hline 9 & Production of machines and related equipment & 27.11 .2019 & Director & Karlovarský & 2812 & 69 & NA & NA & NA \\
\hline 10 & Production of electronic equipment & 27.11.2019 & Director & Karlovarský & 2733 & 233 & $15 \mathrm{Mio}$ & NA & Wages, software \\
\hline 11 & Pharmaceutical & 20.11 .2019 & BOM member & Pardubický & 21 & 224 & $100-160$ Mio & $15 \%$ & Material for testing, \\
\hline 12 & Engineering & 20.12 .2019 & $\begin{array}{l}\text { Managing } \\
\text { Director }\end{array}$ & Pardubický & 28 & 250 & 80 Mio & NA & NA \\
\hline 13 & Research and development & 06.12 .2019 & \begin{tabular}{|l} 
Managing \\
Director
\end{tabular} & Plzeňský & 72 & 80 & NA & NA & R\&D \\
\hline 14 & Production of machines and related equipment & 06.12 .2019 & \begin{tabular}{|l|} 
Managing \\
Director
\end{tabular} & Plzeňský & 2812 & 10 & NA & NA & Expenses, wages \\
\hline 15 & Compensatory and rehabilitation aids & 29.11 .2019 & \begin{tabular}{|l|} 
Managing \\
Director
\end{tabular} & Středočeský & 3250 & 113 & 35 Mio & NA & NA \\
\hline 16 & Office and school furniture & 29.11 .2019 & $\begin{array}{l}\text { Managing } \\
\text { Director }\end{array}$ & Jihočeský & 3101 & 123 & ad hoc & $2 \%$ & $\begin{array}{l}\text { Wages, investment } \\
\text { costs }\end{array}$ \\
\hline 17 & Engineering- optical instruments & 27.11 .2019 & Director & Vysočina & 2670 & 7 & NA & NA & NA \\
\hline 18 & Custom production for aerospace industry & 06.12 .2019 & Director & Jihomoravský & 3030 & 100 & NA & NA & NA \\
\hline 19 & Information and control systems for production & 05.12 .2019 & \begin{tabular}{|l|} 
Managing \\
Director
\end{tabular} & Jihočeký & 6201 & 35 & NA & NA & Wages, services costs \\
\hline 20 & Production of machine tools & 27.11 .2019 & CFO & Vysočina & 2550 & 630 & $5,5 \mathrm{Mio}$ & NA & Material, wages \\
\hline 21 & Furniture & 11.12 .2019 & Finance Director & Vysočina & 3109 & 75 & $1 \mathrm{mio}$ & NA & Wages, testing \\
\hline 22 & $\begin{array}{l}\text { Technologies for wastewater treatment, water treatment and air } \\
\text { treatment }\end{array}$ & 06.12 .2019 & \begin{tabular}{|l} 
Managing \\
Director
\end{tabular} & Jihomoravský & 2223 & 48 & NA & NA & NA \\
\hline 23 & Pharmaceutical & 12.12 .2019 & Finance Director & Jihomoravský & 2120 & 687 & NA & NA & NA \\
\hline 24 & Jet surf production & 17.12 .2019 & Director & Jihomoravský & 3230 & 80 & NA & NA & NA \\
\hline 25 & Accounting, advisory & 7.1 .2020 & Senior Manager & Prague & NA & NA & NA & NA & NA \\
\hline 26 & Pharmaceutical & 15.1 .2020 & \begin{tabular}{|l|} 
Strategy \& \\
Operations \\
Manager
\end{tabular} & Prague & NA & 1300 & NA & NA & NA \\
\hline 27 & R\&D centre & 22.1 .2020 & $\begin{array}{l}\text { University } \\
\text { Relations } \\
\text { Specialist }\end{array}$ & Prague & NA & 4500 & NA & NA & NA \\
\hline 28 & Electrical machinery production & 27.1 .2020 & CEO & Ústecký & NA & 490 & NA & NA & NA \\
\hline 29 & Machine tool production & 30.1 .2020 & CFO & Liberecký & 2841 & 75 & $10+$ Mio & NA & \begin{tabular}{|l} 
Prototype \\
development, wages
\end{tabular} \\
\hline 30 & 3D printing & 30.1 .2020 & \begin{tabular}{|l} 
Managing \\
Director
\end{tabular} & Ústecký & 2229 & 85 & At least & $1 \%$ & Wages \\
\hline 31 & $\begin{array}{l}\text { Production of performance units, production of electronics, } \\
\text { switchers }\end{array}$ & 30.1 .2020 & Finance manager & Ústecký & NA & 355 & NA & NA & NA \\
\hline 32 & Wooden buildings, trusses, trusses, wooden construction panels & 3.2. 2020 & Director & Jihočeský & 4221 & 75 & 2 Mio & NA & Wages, certification \\
\hline 33 & $\begin{array}{l}\text { Research, development, production of machines for the } \\
\text { manufacturing industry }\end{array}$ & 30.1 .2020 & $\begin{array}{l}\text { Managing } \\
\text { Director }\end{array}$ & Liberecký & NA & 200 & $27 \mathrm{Mio}$ & NA & \begin{tabular}{|l|} 
Regular expenditures, \\
wages
\end{tabular} \\
\hline 34 & IT, Smart Cities & 31.1 .2020 & CEO & Zlínský & 6200 & 18 & NA & NA & Wages \\
\hline 35 & Processing of rubber mixtures, tires & 5.2 .2020 & $\begin{array}{l}\text { External Relations } \\
\text { Manager and HR } \\
\text { Manager }\end{array}$ & Ústecký & NA & 1500 & $\mathrm{~N} / \mathrm{A}$ & $\mathrm{N} / \mathrm{A}$ & $\mathrm{N} / \mathrm{A}$ \\
\hline 36 & Oligonucleotide synthesis & 10. 12. 2019 & Director & Královehradecký & 7211 & 38 & 0,33 mil. EUR & $33 \%$ & $\begin{array}{l}\text { Regular expenses, } \\
\text { wages, investment } \\
\text { exp. }\end{array}$ \\
\hline 37 & Manufacturer of ceramic printed circuits, hybrid integrated circuits & 10. 12. 2019 & General manager & Královehradecký & 2611 & 65 & NA & $5-10 \%$ & NA \\
\hline 38 & Production of hazardous chemicals & 7.2. 2020 & CEO & Ústecký & 2013 & 90 & 2 Mio & NA & $\begin{array}{l}\text { Wages, equipment, } \\
\text { tests, laboratory } \\
\text { reports }\end{array}$ \\
\hline 39 & Testing, inspection, certification, homologation and education & 10.2 .2020 & Head of Sales & Prague & 2008 & 330 & NA & NA & NA \\
\hline 40 & Production of briquette presses, software development & 10.02 .2020 & CEO & Jihočeský & 2812 & 66 & NA & $5-10 \%$ & \begin{tabular}{|l|} 
Investment \\
expenditures
\end{tabular} \\
\hline 41 & Services, application development & 02.06 .2020 & Finance Director & Jihomoravský & 6201 & 600 & NA & NA & NA \\
\hline
\end{tabular}

\section{Source: own processing}

